\title{
طب الحالات الحرجة من منظور الفقه الإسلامي
}

دكتور/ محمد منصور صنت الرشيدي

دكتوراه في الشريعة الإسلامية

جامعة الأزهر 


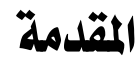

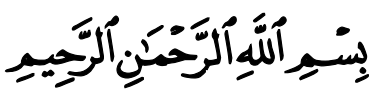

إن الحمد لله نحمده ونستعينه ونستغفره، ونعوذ بالله من شرور أنفسنا، من يهد الله فلا مضل له، ومن يضلل فلا هادي له، وأثهد أن لا إله إلا الهه وحده

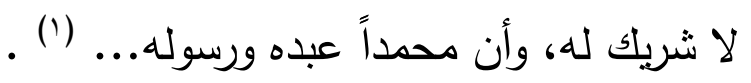

وبعد: فقد جـاءت الشريعة الإســامية، بالعقيدة الحنيفيـة، والأخـلاق

النبويـة، فبهـرت العقول بكمالهـا، وسـحرت الألبـاب بجمالهـا، فهي خاتمــة الديانات، وآخر الرسـالات، وكانت بحق مسك الختام، في صدق الأخبار وعدل الأحكام، وكان من لوازم شمولها، وأدلة عمومها، صلاحها لكل زمان ومكان، وحال وإنسان، على مر الزمان، إلى أن يصير الناس عند المرجع والمصير، فريقين: فريق في الجنة وفريق في السعير ، ومن هنا اهنم الشرع

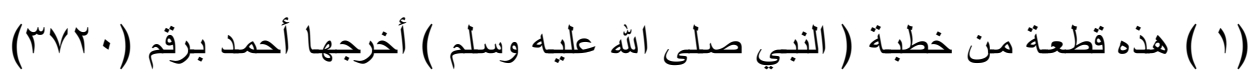

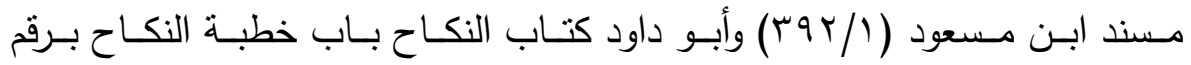

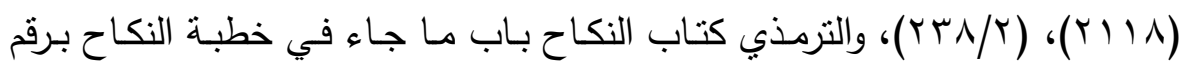

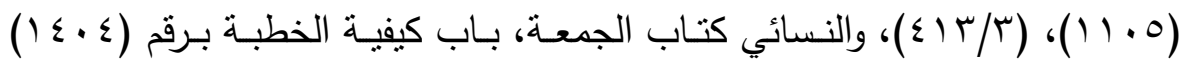

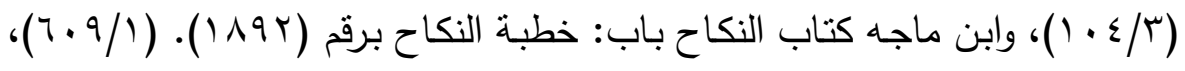

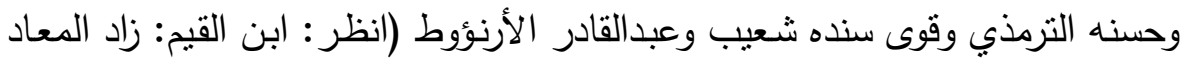

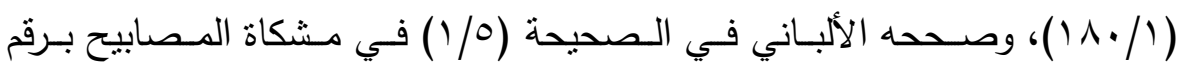

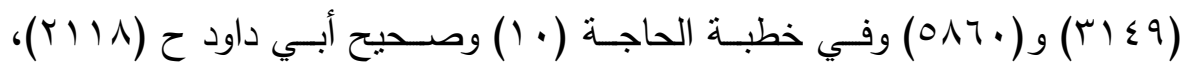

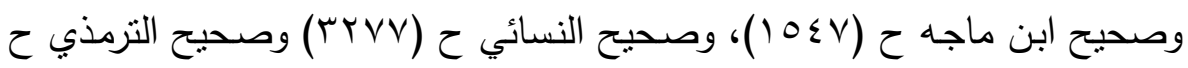

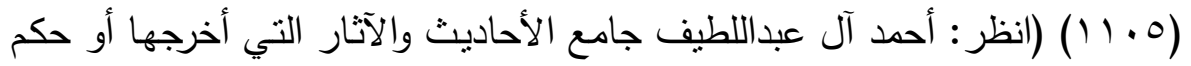

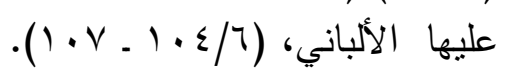


الثربف بالإنسان في دينه وبدنه وعقله وماله وعرضـه، إذ هو خليفة الله في عمارة أرضه، وكان من مقاصد الثرع بناء الفرد بناء سليماً، وتكوينه نكويناً مستقيماً، في جانبين كبيـرين جـامعين لخيـري الدارين: وهما صسلاح الدين وإصلاح البدن، فالأول: شأن العلماء والثاني: شأن الأطباء؛ ولذا قال الإمام الـشافعي -رحمـه الله - (صـنفان لا غنـى للنـاس عنهمـا العلمـاء لأديـانهم والأطباء لأبدانهم)(')

فالطب مجـال واسـع، يحوي العديد من الوقائع، ولمـا كانت الحوادث متجددة، والنوازل متعددة، مسع عدم جواز خلو الحوادث من الأحكام؛ إذ هذا طعـن في شـربعة الإسـالام، فـإن صـاحب المسسؤلية العظمسى، والمـضطلع بالعمليـة الكبرى، هو الفقه الإسـلامي بثوبـه الفضفاض الواسـع، المبني على معرفة النصوص وفهم الواقع، لذا فقد وقع اختياري بعد الاستخارة والاستشارة، على موضـوع أسـمه بالإشـارة، وأرقمـه بالعبـارة، على النحـو التـالي: طـب الحالات الحرجة من منظور الفقه الإسلامي

\section{أهمية الموضوع :}

ا - تكمـن أهميتهـه في تطرقـه لمسائل تتعلق بجانب مهم في حيـاة النـاس اليومية، وهو جانب الحفاظ على الصحة.

(1) البغدادي - موفق الدين عبد اللطيف: الطب من الكتاب والسنة، ت: عبد المعطي

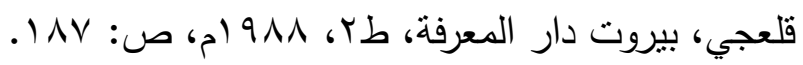


- تظهر أهميته في أن بعض مسائله هي حديث الساعة، ومثنار الجدل في

$$
\text { الساحة، }
$$

- أن كثيراً من مسائله قد كثر النقاش فيها، أو عمت بها البلوى، وتشعبت

$$
\text { الآراء وتحتاج إلى بيان شرعي. }
$$

أهدف فيـه إلـى جمـع آراء المعاصرين كواستقصاء مسسائله، وبيـان أحكامهـا

$$
\text { الثرعية. }
$$

أهدف فيـه إلى الوصـول إلى الحكم الثرعي في هذه المسائل وبحثها بحثناً عصرياً نظراً لأبعادها المستجدة وما ييني عليها من الأحكام الثرعية.

أهدف فيـه إلى الوصـول إلى دراسـة شرعية طبيـة تضاف إلى فقه الطبيب

$$
\text { لتعين الأطباء والفقهاء على حد سواء. }
$$

\section{الدراسة السابقة:}

لـم أقف - حسب علمي - على رسـالة مستقلة وشـاملة جمعـت مسسائل

$$
\text { الموضوع وجاءت الدراسات علي النحو الآتي: }
$$

ا - أحكـام التـداوي والتطبيب في الفقـه الإسـلامي، دراســة مقارنـة، رسـالة مقدمة للحصول على درجة الدكتوراة في الفقه المقارن، إعداد: إبراهيم

$$
\text { مصطفى أدي. }
$$

ץ- القضاء بالقرائن المعاصرة، رسالة لنيل درجة الدكتوراة مقدمة من: عبد الله بن سليمان العجلان. 
r- العمليات الجراحية وأحكامها في الفقه الإسـلامي، بحث تكميلي لنيل درجة الماجستير في الفقه المقارن، إعداد: يوسف بن عبد اللطيف بن

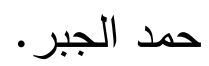

ع- الأحكام الطبية المتعلقة بالنساء في الفقه الإسلامي، رسالة ما جستير

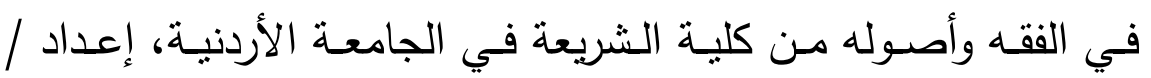

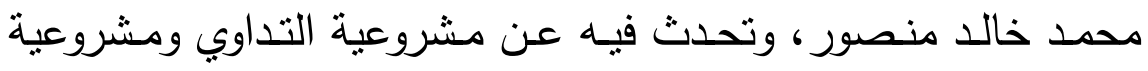
الفحص الطبي ونظر الرجل للمرأة حال القيام بالفحص الطبه وأهلية وندية الطبيب الفاحص ومساعديه بشيء من الإيجاز .

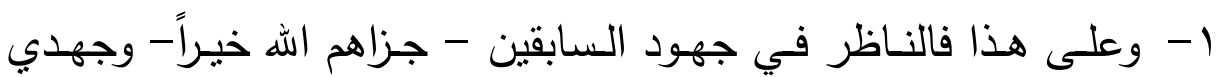

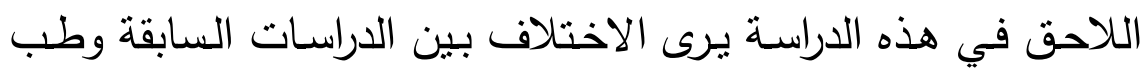

$$
\text { منهج البحث: الحالات الحرجة . ل }
$$

أعتمد في بحث هذه القضية على المنهج الاستقرائي في جمع النصوص وآراء العلماء، والهنهج التحليلي في دراسة هذه النصوص والآراء هذا على سبيل الإجمال، أما التقصيل فعلى النحو التالي: -

1- أصسور المسألة المـراد بحثهـا تصويراً دقيقـاً مـن المراجـع الطبيـة أو اللغوية قبل بيان حكمها: ليتضح المقصود من دراستها.

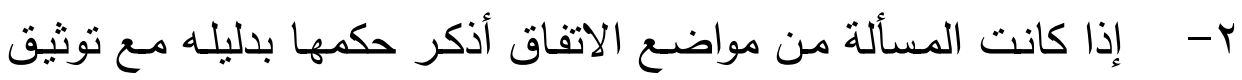

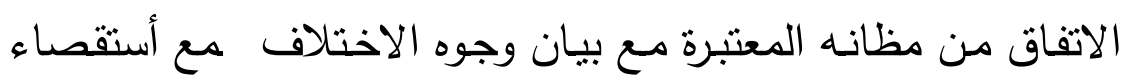

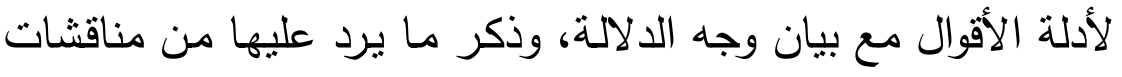
وما يجاب به عنها إن كانت، وأذكر ذلك بعد الدليل مبانشرة. 
و) أذكر الترجيح مع بيان سببه، وذكر ثرة الخلاف إن وجدت.

r- أعتمد على أمهات المصادر والمراجع الأصلية في التحرير والتوثيق

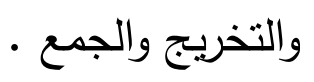

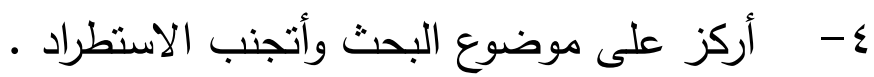

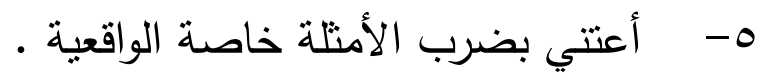

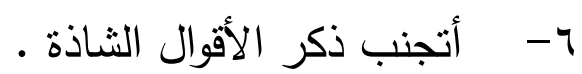

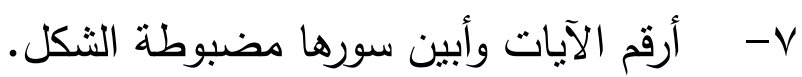

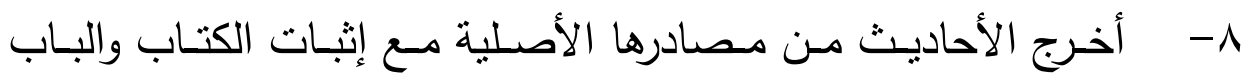

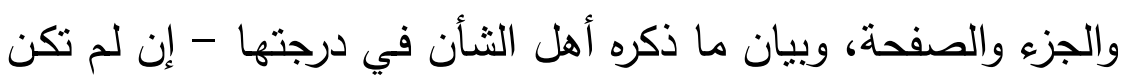
في الصحيحين أو أحدهما - فإن كانت كذلك فأكتفي حينئذ بتخريجها منهما أو من أحدهما. 9- أخرج الآثار من مصنادرها الأصلية، مع الحكم عليها.

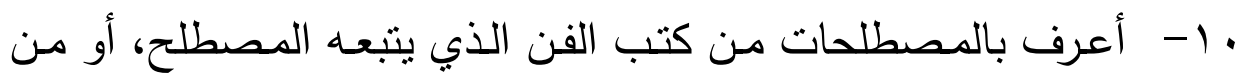
كتب المصطلحات المعتمدة. 11- أوثق المعاني من معاجم اللغة المعتمدة وتكون الإحالة عليها بالمادة والجزء والصفحة .

r أعتني بقواعد اللغة العربية والإملاء، وعلامات الترقيم، ومنها علامات

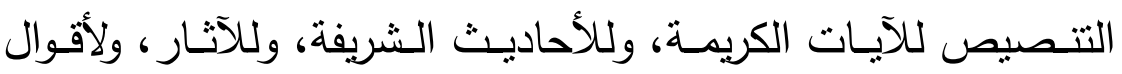

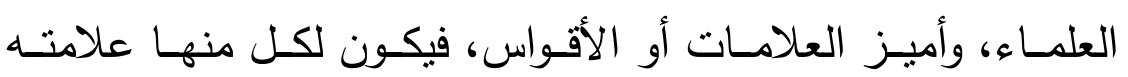
الخاصة. rا - أجعل الخاتمة متضمنة أهم النتائج والتوصيات التي رأيتها من خلال البحث. 
جاء البحث في مقدمة وثلاثة مباحث علي النحو الآتي • المبحث الأول: المراد بالحالات الحرجة وما يندرج تحتها من أمراض. المبحث الثاني : طب الحالات الحرجة بين علماء الأصول والققه . المبحث الثالث : التكييف الفقهي لطب الحالات الحرجة. الخاتمة وبها أهم النتائج والمصادر والمراجع • 
المبحث الأول : المراد بالحالات الحرجة وما يندرج تحتها من أمراض.

المطلب الأول معلومات عامة عن طب الحالات الحرجة :

معلومات عامة عن العناية المركزة:

يعد طب الحالات الحرجة بمفهومة الحديث من أحد أحدث فروع الطب نشأةً وهو بصفة عامـة أكثر فروع الطب استهلاكاً للموارد وارتفاعاً لتكلفة العلاج ومن أكثرهاً اعتماداً علي التكنولوجيا الحديثة هو أحد فروع الطب الحديثة وهو معني بتقديم دعم متقدم للحياة أو لأعضاء الجسم المصابه للمرضسى ذوبي الحاله الصحية الحرجة ويتم ذلك داخل مـا يسمي بوحدة العنايـة المركزة أو وحدة الرعاية المركزة intensive care unit ما هي العناية المركزة هي وحدة مهمـة لرعايـة المرضى الذين يعانون من أمراض خطيرة وتتكون من فريق طبي متكامل برئاسة طبيب متخصص (رئيس القسم) إضافة إلي أطباء متخصصين في طب العناية المركزة وممرضين وممرضات وأخصائيوا علاج طبيعي وأخصائيو عـلاج تتفسي واختصاصيوا تخدير كل هؤلاء يوجدون لمراقبـة حالة المريض سـاعة دخوله إلى المستشفى وحتى مغادرتها مـا هي الحالات التي تستدعي دخول المريض إلى العناية المركزة؟ المرضـى الذين يحتـاجون إلـى العنايـة المركزة عـادةً مـا يكونـون ذوي حالـة صحية حرجة للغاية مما بتطلب الحاجة لمراقبة ودعم استقرار أجهزة الجسم المهمة لاستمرار الحياة لللك لابد أن يتم تحويل المريض من غرفة الحوادث 
أو عن طريـق جناح الجراحة أو الباطنية ولا بـد من الحصول على مراجعة ومن ثم موافقة من رئيس العناية المركزة

سنذكر هنـا بعض هذه الحـالات الخطيرة أمراض القلب الحوادث (سبارات، غرق، حروب) ارتفاع ضـغط الدم المفاجئ المشاكل التففية الحادة بسبب الربو أو الالتهابات الصدرية مشاكل مرض السكر ما بعد الجراحات الكبري وذلك لعدم استقرار حالتهم خلال الساعات أو الأيـام الأولي الحاسمة ما بعد العملية مثل عمليات القلب والصدر والجهاز الهضدي الكبري وجراحات المخ والأعصاب كسور مضاعفة ومتعددة الجلطات الدماغية الحروق الثديدة حيث يقوم المختصون في العنايـة المركزة بعملهم كالتالي المحافظة على استقرار الدورة الدموبة لضمان استمرار تدفق الدم المحمل بالأكسجين والمغذيات لكافة أنحـاء الجسم والحفـاظ علـي ضـغط الـدم مـن أي تغيـرات تـضر بوظـائف الأعضاء (ارتفاع ضنط الدم / هبوط ضنظ الدم (، المحافظة على استقرار الجهاز التنفسي وذلك لدعم القنوات التتنفية ووظائف التنفس مثنل استخدام جهاز التنفس الصناعي ، المحافظة على استقرار وظائف الكلي وذلك للحماية مـن وعـلاج الفـشل الكلـوي الحـاد المحافظـة على اسـتقرار وظــائف القلب المحافظـة على اسـثقرار وظـائف الكبـد عـلاج اختنلال أمـلاح الـدم ونسبة

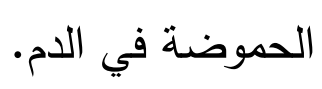


تخصص منفصل أم تخصص داخل تخصص؟

حتي زمن قريب كانت وحدات الرعاية المركزة تدار بشكل كامل بواسطة أطباء التخدير كعمل إضافي داخل التخصص ومع حدوث التطور الهائل المعرفي والتكنولوجي في علم طب الحالات الحرجة، ظهرت الحاجـة لوجود أطباء متخصصين في هذا المجال وبرغم ذلك ما زال هذا التخصص في كثثر من البلاد حكراً علي أطباء التخدير وفي بلاد أخرى أمريكا يشترط للتخصص في هذا المجال الحصول علي تدريب مسبق في مجال أخر مثل التخدير أو الجراحة العامة أو أو الباطنة العامة

ثم يلي ذلك الحصول علي تدريب متخصص في طب الحسالات الحرجـة وكثيراً مـا يرغب أطباء العناية في الحصول علي تدريب موازي إلي جانب تخصصهم بالرعاية مثل القلب أو الأمراض الصدرية أو أمراض الكلي وحدة مفتوحة أم مغلقة؟

تشير دراسات بشكل واضـح ومتكرر لتحقق خدمة أكثر كفاءة ونتائج أفضل لعلاج المرضي داخل الوحدات التي تدار من قبل أطباء متخصصين بطب الحالات الحرجة منواجدين علي مدارالساعة بالرعاية المركزة مقارنةً بالوحدات المفتوحة والتي تدار بواسطة التمريض مع وجود أطباء من كافة التخصصات يقومون بالمرور علي الحالات التي تخصهم داخل الرعاية وحدة صغيرة أم كبيرة؟ الدراسات الطبية تثير إلى وجود علاقة بين حجم وحدة العناية المركزة 
وبين كفاءة الرعايـة المقدمة للمرضـى. حيث أشـارت الدراسـات لقدرة العنايات المركزة الأكبر حجمـاً علي تحقيـق نتـائج أفضل فيمـا يتعلـق بنجـاح عـلاج

$$
\text { المرضي ذوي الحالات الحرجة. }
$$

أشكال وحدات العناية المركزة المتخصصة.

يوجد عدة أشـكال للعنابـة المركزة قد تثواجد جميع هذه الأشكال في نفس المستشفى وقد يتواجد بعضها فقط بحسب حجم ومكان المستشفى ونوعيـة الخدمات التي يستطيع تقديمها وتوفيرها للمرضسى وأحيانا تكون وحدة عناية مركزة واحد تشمل جميع التخصصات وأحيانا يكون الاختلاف فقط في اسم وحدة العناية المركزة

\section{المطلب الثاني: حقيقة طب الحالات الحرجة}

الموت عند أهل اللغة: ضد الحياة. وحروفه: الميم والواو والتاء: أصل صحيح يدل على ذهاب القوة من الثـئ وهو السكون وعدم الحركة' .

والموت فى اصطلاح الفقهاء: هو مفارقة الروح الجسد׳⿳ . وعرفه الباجورى بأنه: عدم الحياة عما من شأنه أن يكون حياّ •

ا لسان العرب لابن منظور مادة موت

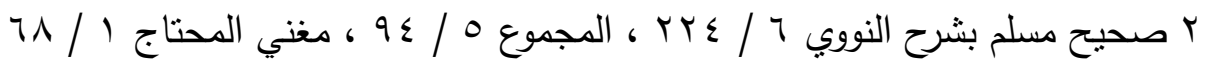

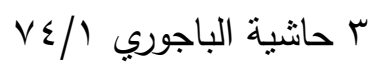




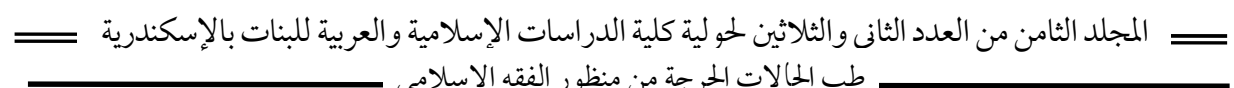

وتعريف الثيخ الباجورى يشمل السقط ميتا قبل أن تدب الروح فيه. وقد ذكر

الدكتور بكر أبو زيد فى حقيقة الموت عند الفقهاء أنها تتخلص فى أمرين' .

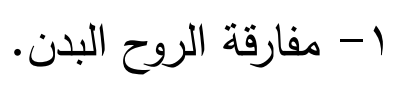

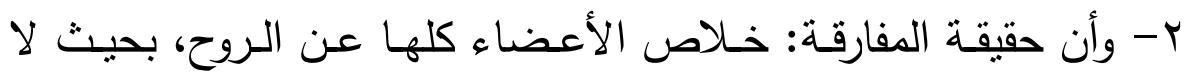
يبقى جهاز من أجهزة البدن فيه صفة حياتية. 
المطلب الثانى

\section{علامات الموت عند الفقهاء والأطباء}

أما علاماته عند الفقهاء فإنها تتخلص فى' :

انقطاع النفس ، استرخاء القدمين ، انفصال الزندين' ، ميل الأنف ، امتداد

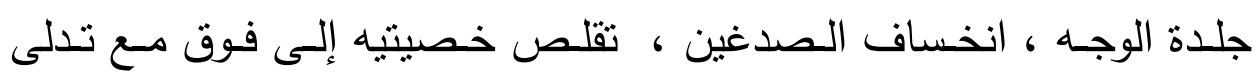
الجلدة، برودة البدن ، إحداد البصر .

وهذه الأمارات ظاهرة تدرك بالمشاهدة والحس ويشترك فى معرفتها عموم

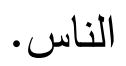

وأمــا علامـات المـوت عنـــ الأطبـاء: فمنهـا علامـات أساسـبة وأخـرى

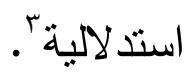

أما علامات الموت الأساسية: فهى توقف النفس والقلب والدورة الدمويـة توقفا لا رجعة فيه، وهى العلامات المميزة والفارقة بين الحياة والموت.

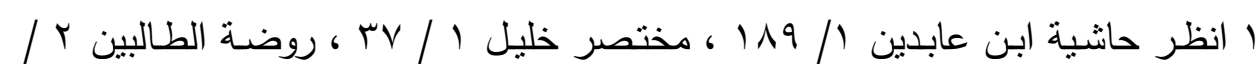

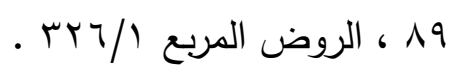

r الزندان هما الساعد والزراع والأعلى منهما هو الساعد والأسفل هو الزراع ـ انظر لسان العرب مادة زند

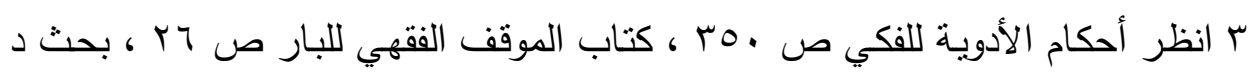

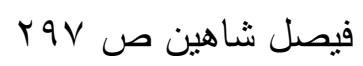


وقد يتوقف القلب والنفس بسبب إجراء عملية جراحية أمسا الدورة الدمويـة فلا تتوقف ولا لمدة ثوان، فلا يكون فى هذه الحالة موتا.

وأما العلامات الاستدلالية للموت: فهى التى يستدل بها على توقف القلب والدورة الدموية توققا لا رجعة فيه. وتتلخص فيما يلى:

أ- ارتخاء العضلات وعدم استجابة الجثة لأى تتبيه حسى، وبروز حدقة العين.

ب- مـا يعرف بالزرقـة - الرميـة - وهـى زرقـة ناتجـة عن توقف الدورة

$$
\text { الدموية وخاصة فى الأجزاء العليا من الجثة. }
$$

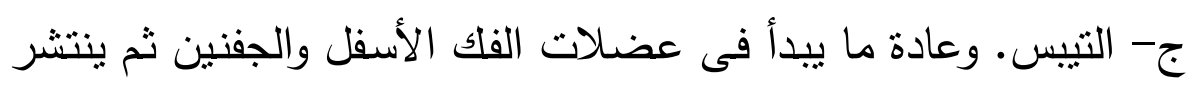
فى الوجه والعنق والصدر والذراعين والجذع وأخيرا فى الأرجل.

د- التعفن. وهو تحلل أنسجة الجسم بواسطة ميكروبات التعفن وخاصة فى الأحشاء ويبدأ فى الجو الحار بعد مـرور (عابعاعة ) من الوفاة ويتأخر عن ذلك فى الجو البارد.

وقد أجمل بعض الباحثين العلامات الدالة على موت الدماغ فيما يلى :

ا - الإغماء الكامل وعدم الاستجابة لأى مؤثرات لتتبيـه المصاب مهما

$$
\text { كانت قوية }
$$

ب- ب - بم الحركة التلقائية

ץ- عدم التنفس لمدة ثـلاث أو أربع دقائق [على خـلاف بين المدارس الطبية] بعد إبعاد المنفسة. 
ع - عدم وجود أى نشاط كهربائى فى رسم المخ بعد امراره بطريقة معينة

$$
\text { معروفة عند الأطباء. }
$$

ه- عدم وجـود أى من الأفعال المنعكسة مـن جذع الدماغ الدالـة على معرو

$$
\text { نشاط الجهاز العصبى منل: }
$$

- عدم حركة حدقة العين للضوء الثديد.

- ل ل يرمش المصاب رغم وضـع قطعة من القطن على قرنية العين. - ل ل التحرك مقلة العين رغم إدخال ماء بارد فى الأذن. - ل ال يقطب المصاب جبينه رغم الضغط على الجبين بالإبهام. - عدم التحكم أو الكحة عند لمس الحنك وباطن الحلق بالإبهام وعدم اسجابة عضلات الحنجرة لتحريك أنبوب القصبة الهوائية. - عدم وجود حركة الدمية عند تحريك الرأس. ويجب إعادة فحص وظائف الدماغ من فريق أخر بعد مرور عدة ساعات على خلاص فعندما يصاب جذع الدماغ وهو المتحكم فى جهازى التنفس والقلب والدورة الدموية فإن توقف جذع الدماغ وموته يؤدى لا محالة إلى توقف القلب والدورة الدموبة والتنفس ولو بعد حين. 


\section{المبحث الثاني}

\section{طب الحالات الحرجة بين علماء الأصول والفقه}

ويعد مدار الأحكام في طب الحالات الحرجة قائما علي الظن واليقين حيث يمكث المريض في مرضسه عدة شهور فلا بـ من بيان موقف العلماء حول الظن واليقين من أجل بناء الأحكام .

\section{المطلب الأول: الكتاب}

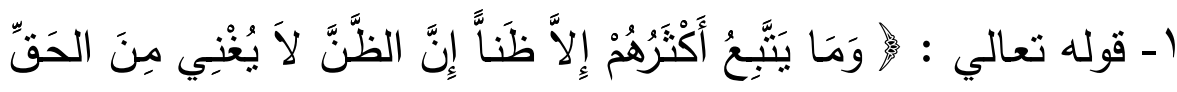

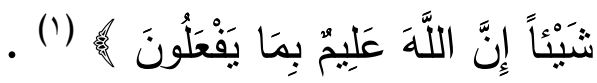

\section{وجه الدالة:ة}

قال ابن جرير(؟) - رحمه الله - في موطن الاستدلال - بهذه الآية " إن الثك لا يغني من اليقين شينًا ، ولا يقوم في شئ مقامه ،

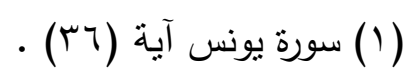

(Y) هو : محمد بن جرير بن يزد أبو جعفر ، الطبري ، الدفسر المؤرخ الفقهية الدجتهد

$$
\text { المطلق ، ولد في : هو بن جامير }
$$

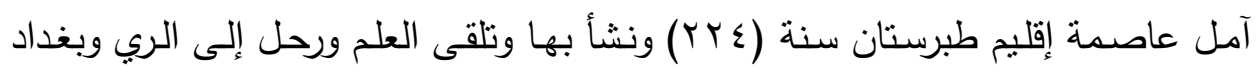

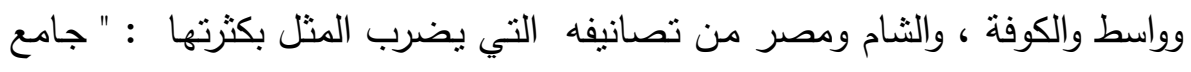

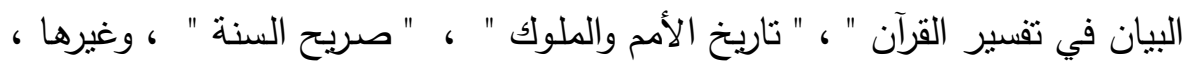

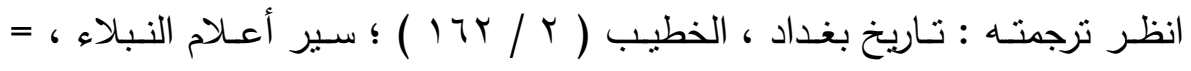




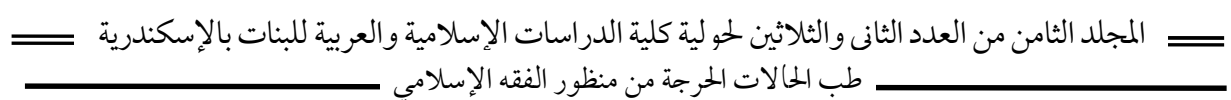

ولا ينتفع به حيث يحتاج إلى اليقين "( ) .

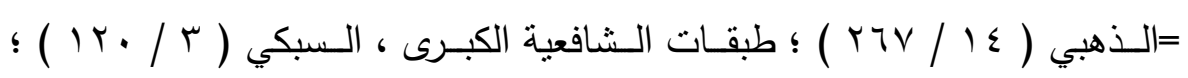

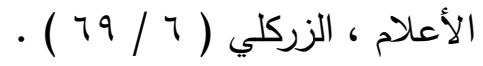

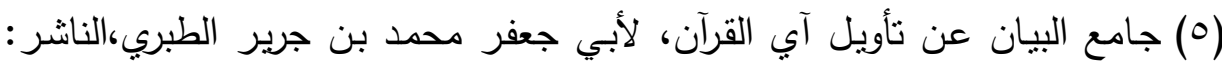

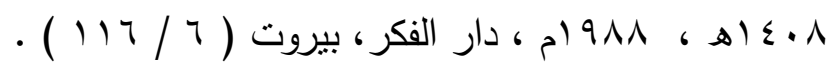




\section{المطلب الثاني : النيُّنة}

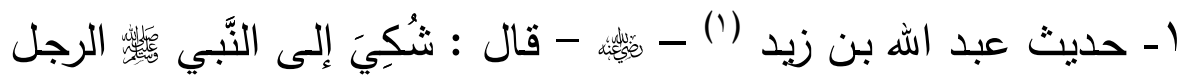

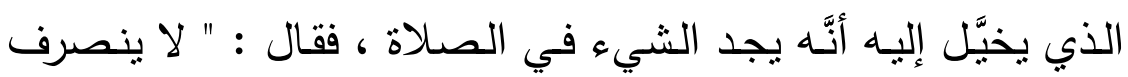

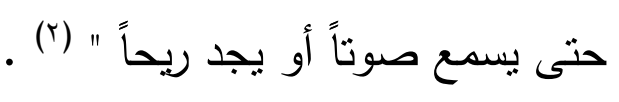

وجه الدلالة:

قال الإمـام النووي - رحمـه الله - : " هذا الحديث وهذا الحديث أصل من أصول الإسلام، وقاعدة عظيمة من قواعد الفقه وهي أن الأشياء يحكم ببقائها على أصولها حتى يتيقن خلاف ذلك، ولا يضر الثنك الطارئ عليها فمن ذلك

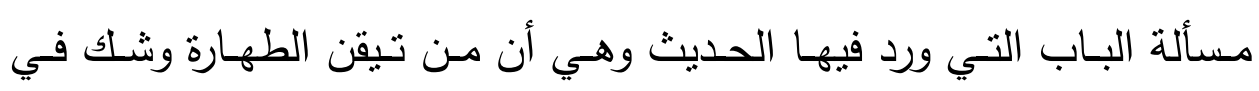

(1) هو : عبد الله بن يزد بن عاصم ، الأنصاري المازني ، شهـ المشاهد كلها ، وقيل :

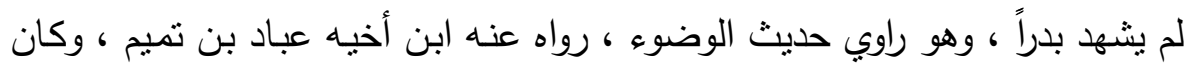

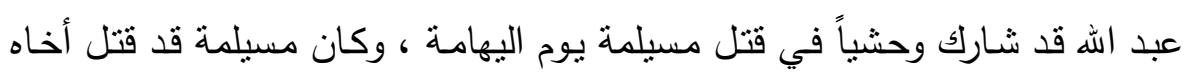

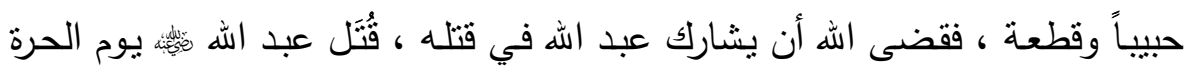

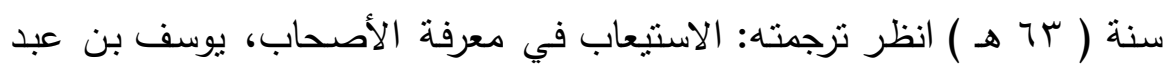

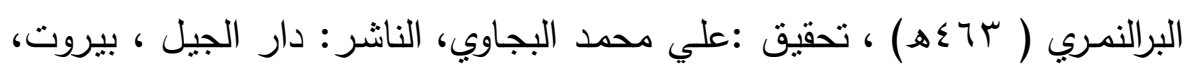

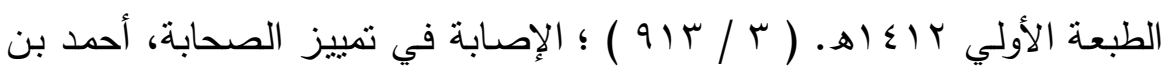

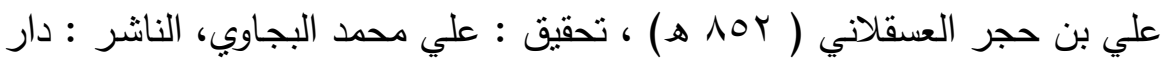

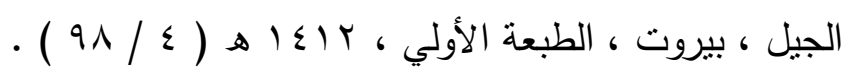

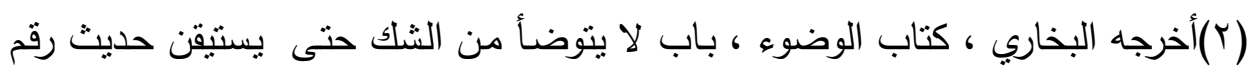

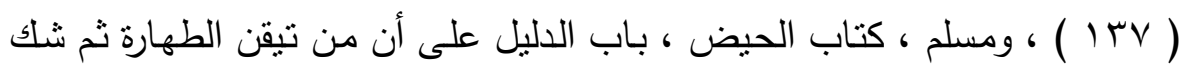

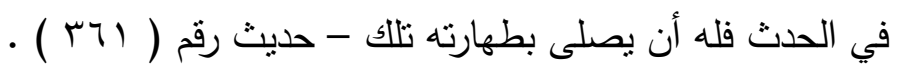


الحدث حكم ببقائه على الطهارة ، ولا فرق بين حصول هذا الثك في نفس الصصلاة وحصوله خـارج الصصلاة هذا مذهبنا ومـذهب جمـاهير العلمـاء مـن

السلف والخلف وحكي عن ماللك"( )

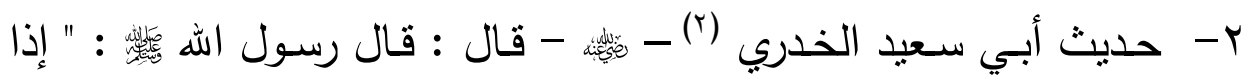

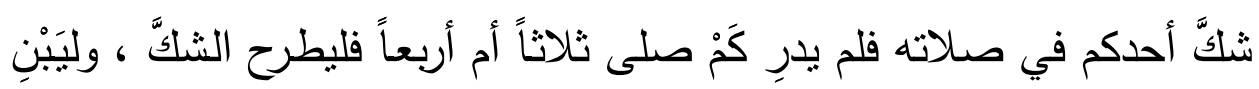
على ما أستيقن ثُ ليسجد سجدتين قبل أن يسلم فإنْ كان صلى خمساً شَفَعَتْْ له صلاته ، وأن كان صلى إتماماً لأربع كانتاً ترغيماً للثنَّيطان "(") .

( (1)شرح صحيح مسلم، يحئُ بن شرف النووي ( TV7 هـ) ، الناشر : دار إحياء التراث

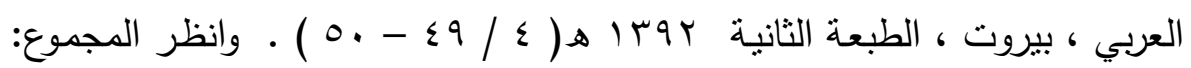

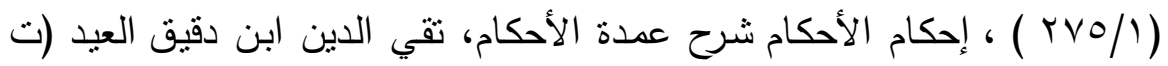

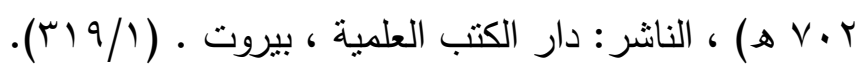

(Y) هو : سعد بن مالك بن سنان الأنصاري الخزرجي ، مشهور بكنيته ، استصغر يوم

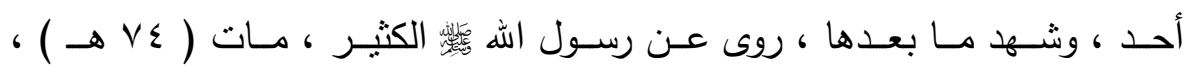

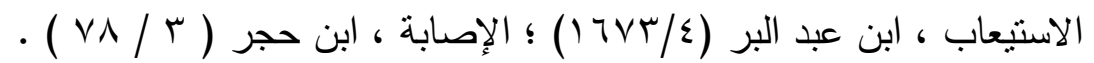
(r) أخرجه مسلم ، كتاب المساجد ، باب السهو في الصلاة والسجود لـه ، حديث رقم . (OVI) 


\section{وجه الدلالة :}

قال ابن القيم(') - رحمة الله - : " لهـا كان الأصل إبقاء الصلاة في ذمته

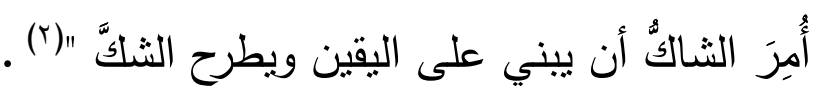

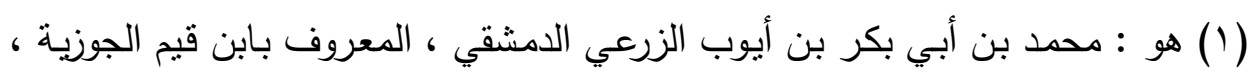

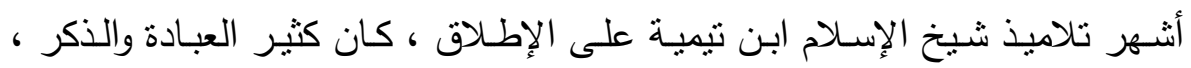

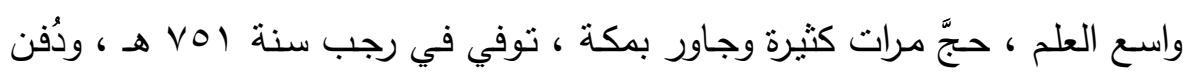

$$
\text { بمقابر الباب الصغير بدمشق. }
$$

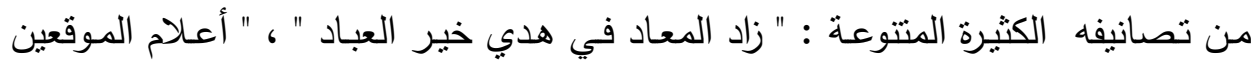

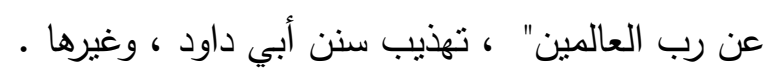

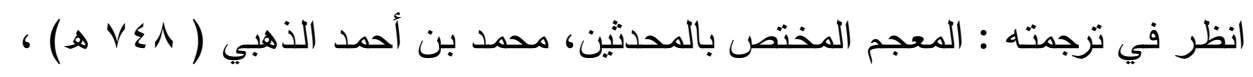

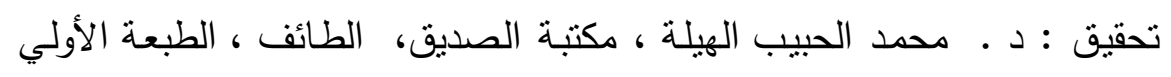

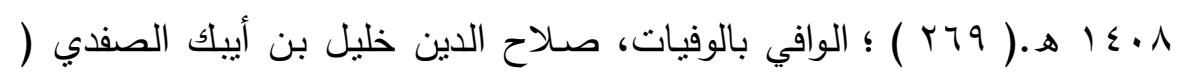

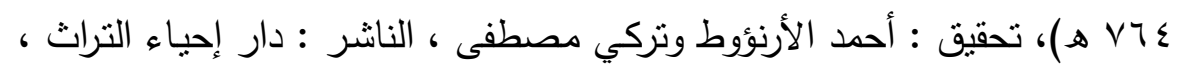

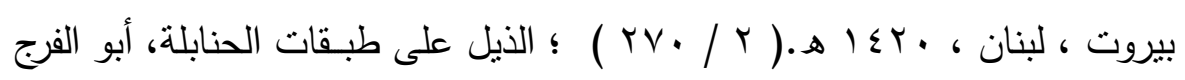

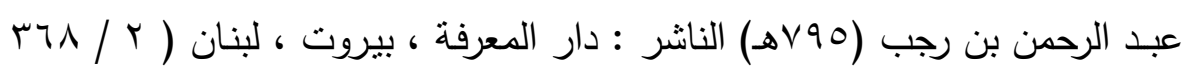

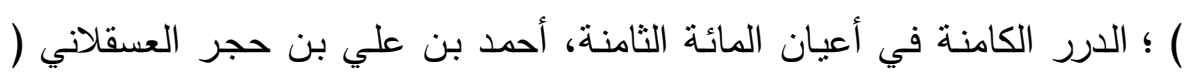

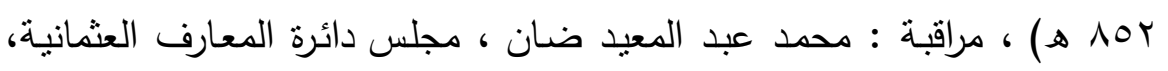

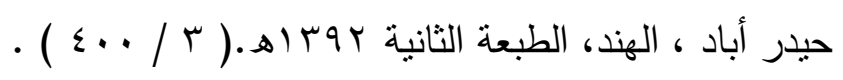

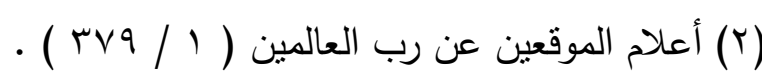


وقال ابن عبد البر (') - رحمـه الله - مبيناً فقه الحديث : " في هذا الحديث من الفقه أصلٌ عظيهٌ جسيمٌ مُطرِّدِّ في أكثر الأحكام ، وهو أنَّ اليقين لا يزيل الثكُّ وأنَّ الثيء مبنى على أصله المعروف حتى يزبله يقين لا شك (Y)" (Y)

\section{المطاب الثالث: الإجماعاع:}

وقد أجمـع العلمـاء على هذه القاعدة عمومًا كالقرافي - رحمـه الله - حيث قـال : " أجمع العلماء على أن من أيقن بالحدث وشك في الوضوء أن شكه

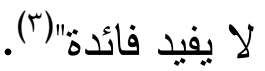

(1) هو : يوسف بن عبد الله بن محمد بن عبد البر ، أبو عمر النمري القرطبي المالكي

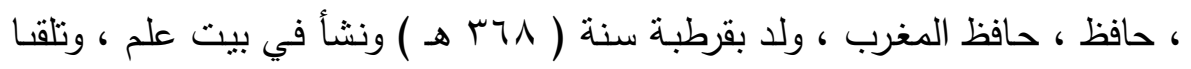
العلم في بلده ورحل من أجله في بـلاد الأندلس ، قال الذهبي : " كان أماما دينا ثقة فئه

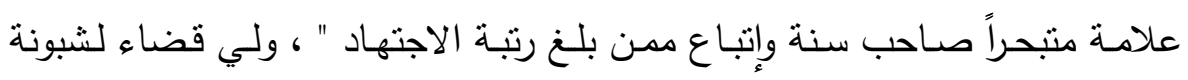

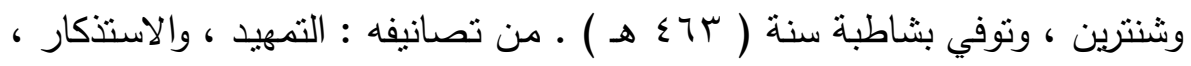

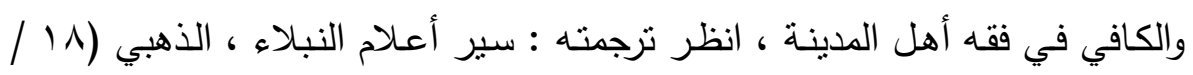

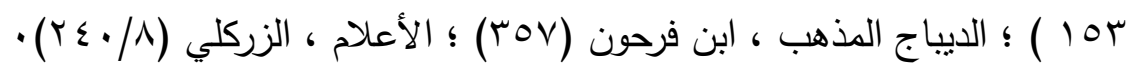
(Y) التمهيد لما في الموطأ من المعاني والأسانيد ، أبو عمر يوسف بن عبد الله بن عبد البر النمري

الناثـر : وزارة عمـوم الأوقـاف والـشؤون الإســلامية ، المغـرب ، INV هـ ، تحقيـق :

$$
\text { مصطفى بن أحمد العلوي، محمد عبد الكبير البكري ( 0 / هץ ) • }
$$

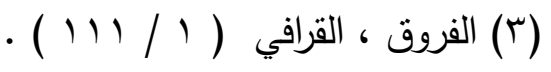


أما من حكي الإجمــاع على فروع منــدرجة تحت هذه القاعدة ابن عبد البر - رحمـــه الله - حيث قــال : " أجمـع العلمـاء على أن مـن أيقن بالـحدث

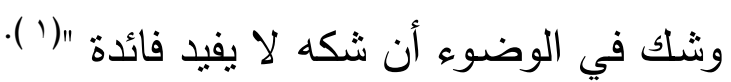

وابن حزم(r) - رحمه الله - حيث قال : " وأجمعوا أن من أيقن الحدث وشط في الوضوء أن شكه لا يفيد فائدة "(") .

( ) التمهيد لابن عبد البر rV/0 ) ، الاستذكار، أبو عمر يوسف بن عبد الله بن عبد البر النمري ، الناشر : دار الكتب العلمية ، بيروت ، الطبعة الأولى ، ابك اهـ ،

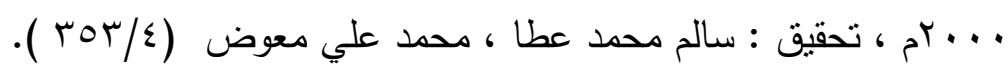

(Y) هو علي بن أحمد بن سعيد بن حزم الظاهري ـ أبو محمد . عالم الأندلس في عصره

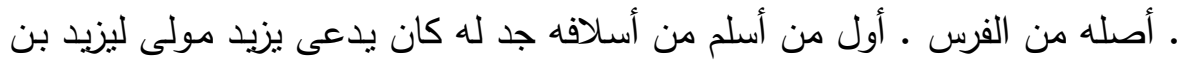

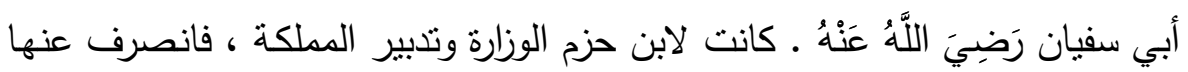

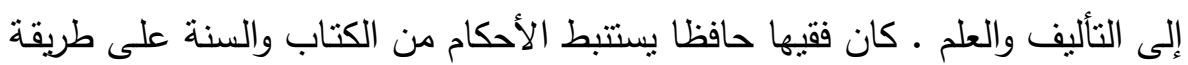
أهل الظاهر ، بعيدا عن المصانعة حتى شُبِّه لسانه بسيف الحجاج . طارده الملوك هـ حتى توفي مبعدا عن بلده ـ كثير التآليف ـ مزقت بعض كتبه بسبب معاداة كثير من الققهاء لله .

من تصانيفه : " المحلى " في الفقه ؛و " الإحكام في أصول الأحكام " في أصول الفقه ؛ و " طوق الحمامة " في الأدب . انظر ترجمته : الأعلام للزركلي ( / / 9 ه). (r) مراتب الإجماع في العبادات والمعاملات والاعتقادات ، علي بن أحمد حزم (بـ؛ هـ) ، دار الكتب العلمية ، بيروت (r/T/r ) ) 


\section{رإيعًا(لعقل :}

هناك مجموعة كبيرة من الأدلة العقلية لهذه القاعدة (') ، ومن تلك الأدلة ما

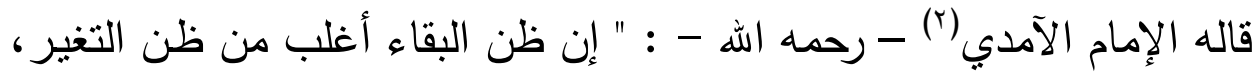
وذللك لأن الباقي لا ينوقف على أكثر من وجود الزمان المستقبل ومقارنة ذلك إنك

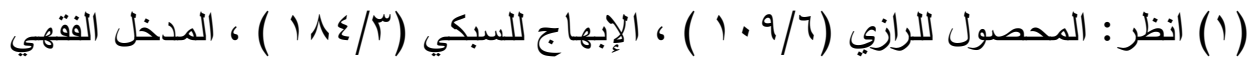

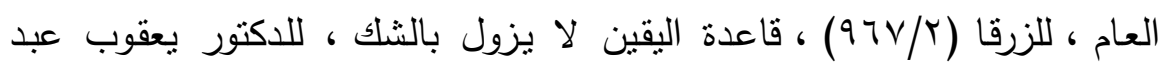

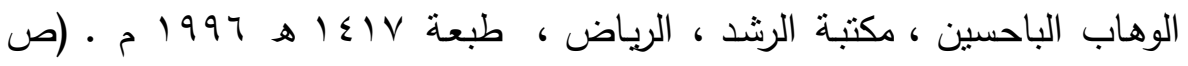

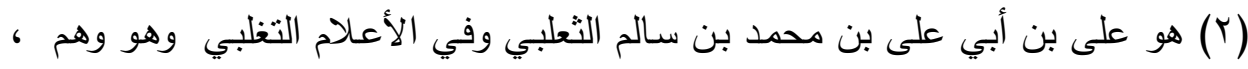

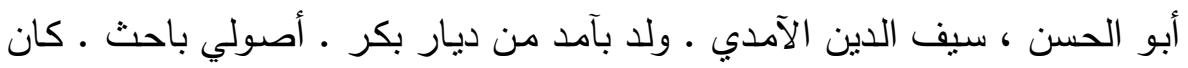

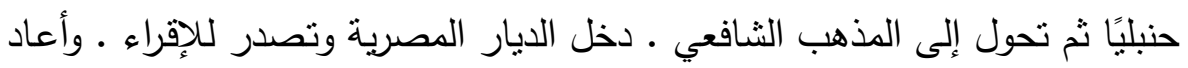
بدرس الشافعي وتخرج بـه جماعة . حسده بعض الفقهاء ونسبوه إلى فساد العقيدة والتعطبل ومذهب الفلاسفة ـ فخرج منها إلى البلاد الثامية ، وتوفي بدمشق ، من :تصانيفه " الإحكام في أصول الأحكام " ؛ و" أبكار الأفكار " في علم الكلام ؛و" لباب الألباب"

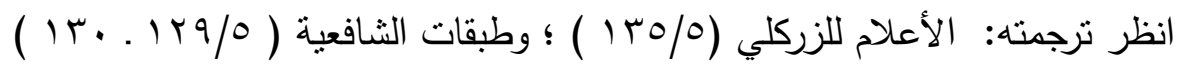




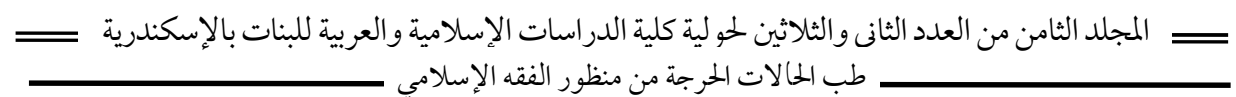

الباقي لله كان وجودًا أو عدمًا ، أمسا التغير فمتوقف على ثلاثة أمور وجود الزمان المستقبل ، وتبدل الوجود بالعدم أو العدم بوجود ومقارنة ذلك الوجود

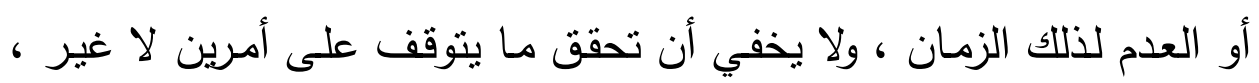

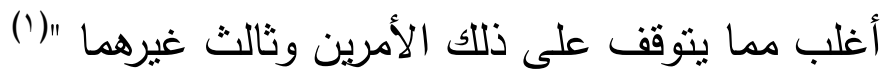




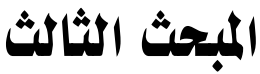

\section{التكييف الفقهي لطب الحالات الحرجة}

إن سبب الخلاف بين الأطباء: برجع إلى مدى تحقق اليقين فى موت هذا الشخص الذى مـات جذع دماغـه مـع عدم توقف القلب والنفس حال كونـهـ تحت أجهزة الإنعاش. تحليل محل النزاع عند الأطباء:

بالاستقراء نجد أن تقسيم الأطباء لأحوال توقف القلب والدماغ ينقسم إلى ثلاثة أحوال:

الحال الأول: اجتماع موت كل من المخ وعضلات القلب وما تشمله من دورة دموية وتتفسية، إن الموت يبدأ بتوقف القلب، والذى يعقبه فورا توقف التنفس وفقدان الوعى، ثُ تموت الأعضاء - بدءا بالمخ - فى الدقائق الأولى. الحال الثانية: نوقف القلب والتنفس دون المخخ وجذعه: وهنا يمكن إسعاف هذا الشخص بجعل مضخة بديلة تضخ الدم وتسيره عبر

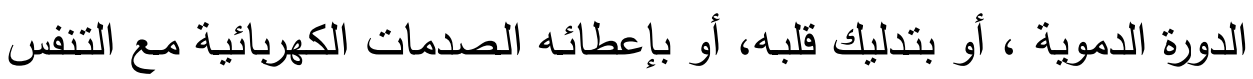
الصناعى. ولا يكون صاحب هذه الحال ميتا وإنما يعد من المرضى. الحال الثالثة: تلف المخخ وجذعه دون رجعة. 
ويكون القلب والتنفس قابلا للتشغيل عن طريق المنفسة بأجهزة الانعاش، فهل

تكون هذه الحال موتا للإنسان ونهاية لحياته ليستحق صاحبها شهادة وفاة؟ اختلف الأطباء فى ذلك على ثلاثة اتجاهات على النحو الآتى:

الاتجاه الأول: يرى أن موت المخخ عند الإنسان يعنى وفاته قطعا، حتى ولو كان القلب والجهاز التتفسى يعملان تحت أجهزة الانعاش، ويستحق صاحبه شهادة وفاة. وإلى هذا ذهب أكثر الأطباء. وأهم حججهم ما يلى:

ا - أن عمل القلب بعد موت الدماغ مؤقت لفترة قصيرة دون أدنى أمل

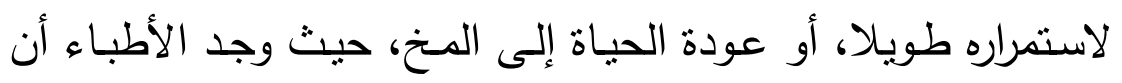
كل من أصيب بموت الدماغ انتهى به الأمر مع بذل كل الإمكانيات الطبية الحديثة، إلى توقف قلبه بعد زمن قصير (ساعات إلى أيام) باستثناء حالات قليلة أمكن المحافظة فيها على نبضات القلب لفترة

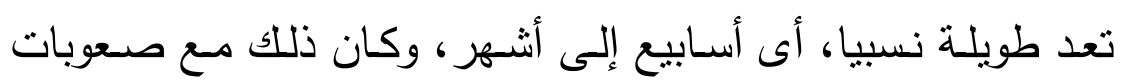

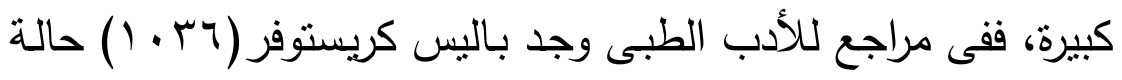

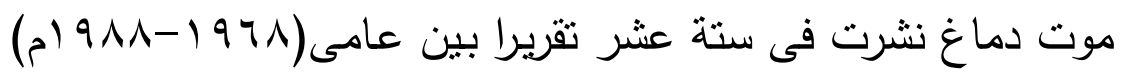

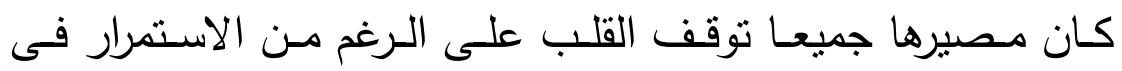

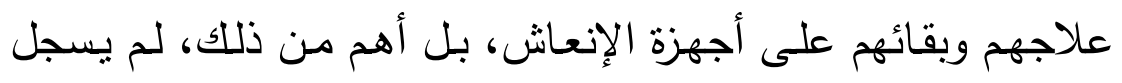

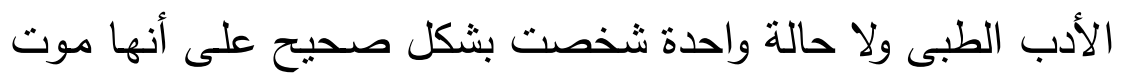

$$
\text { دماغى ثم عادت إلى الحياة. }
$$


r- أن هذا التعربف الجديد للموت( الموت الدماغى ) لا يعنى التخلى عن اعتبارات الاحترام والتعامل الوقور المناسب مع جسد الميت، فلا ندفن إنسانا يتنفس.

ب- أن الميـت دماغيـا لاتظهـر عليـه أيـة أمـارات للحيـاة الحقيقيـة، ومـا يحدث فى بعض الحالات المرضية من: فتح العينين، أو الحركة، أو الاحتفاظ بدرجة الحرارة، ونحوها، فهذايعنى عدم موت المخ كليا، ولا يجوز تشخيص منثل هذه الحالات موتا دماغيا. ع - أن تحديد الوفاة بموت الدماغ قد سـاد العمل بـه فى معظم البلدان المتقدمة خـلال العقود السابقة، وحقيقة الموت واحدة للإنسان، يجب ألا تختلف بـاختلاف البلدان؛ لأنه وضـعت علامـات واضـحة للوفـاة الدماغية، وأنها تعادل وفاة الجسد، وأنه لم يرجع أحد استوفى شروط النشخيص إلى الحياة، وقد كانت الدراسات واضحة فى مصداقية هذا المبدأ، سواء الدراسات على الحيوانات أو الإنسان، وأن النقد يجب أن يوجـه لـشروط التشخيص إذا كـان فيهـا خلـل، لـيس لمبـدأ الوفـاة

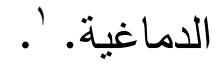

الاتجـاه الثانى: يـرى أن موت المـخ هو أثـد خطرا على حيـاة الإنسان، ولكنه ليس موتا حقيقيا برخص فى إصدار شهادة الوفاة.

وإلى هذا الذهب بعض الأطباء، منهم: الدكتور صفوت حسن لطفى، والدكتور رؤوف محمود سلام. وحجتهم ما يلى:

( ) حقيقة الموت والحياة في القرآن والأحكام الشرعية ، د. توفيق الواعي، من بحوث

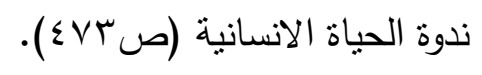


1- إن الأشـخاص الذين تتطبق عليهم معايير المـوت الدماغى تظهر

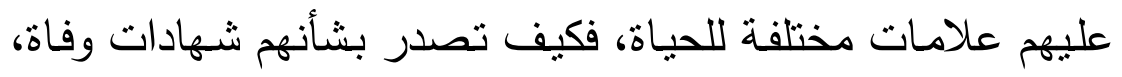
فقد ثبت فى مراكز طبية عالمية مختلفة أن ما بين علامات الحياة التى ظهرت على هؤلاء المرضى المحكوم عليهم بالموت دماغيا ما مانه يلى : أ- استمرار الأفعال المنعكسة من سعال وقئ، بل ويحافظ بعضهم على درجة حرارته.

ب- - النشاط العصبى العضلى، والارتعاشات العضلية. ج- الاستجابة المنعكسة فى النشاط الدموى على شكل ارتفاع فى معدل النبض، وفى ضغط الدم استجابة للتحدى فى حالة الاختتاق، أو استجابة للمثثر الجراحى خلال حصد الأعضاء'.. د- اسـتمرار الحيـاة الخاملـة، فيطــول شـعره وأظــافره، ويهـضم الطعـام ويمنصها، وغير ذلك.

ץ- إن تعريفـات مـوت الـدماغ تختلف عند كل مـن: الولايـات المتحدة الأمريكية، وكندا، والمملكة المتحدة(انجلترا)، وفرنسا. بحيث يمكن أن تعد الحالة "موت دماغ" فى بلد وليست كذللك فى بلد آخر ، ولذلك رفضت 
بعض البلاد المتقدمـة كاليابـان والدنمارك فكرة المـوت الدماغى كحقيقة

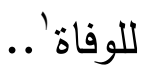

ب- إن الجدل دائر بين الأطبـاء بـشأن صـحة أحدث الوسـائل والطرق الفنيـة لتشخيص المـوت الدماغى، فالرسـم الالكترونى للـماغ الذى كان يستخدم فى أول الأمر لنشخيص موت الدماغ ثبت مؤخرا أنه غير مالأم لتشخيصه، واختبـار الاختتـاق الـى شـاع اسـتخدامه لتشخيص المـوت الدماغى يتعرض الآن لجدل شديد بصدد تطبيقاته، سـواء بالنسبة لمدة استمرار الاختناق، أو مستوى ثانى أكسبد الكربون، أو المدة السابقة على الأكسجة، فهى تختلف من مركز إلى آخر.

ع- إن الدكتور ديفد-هيـلـ- أسـتاذ التخدير بجامعـة كمبردج- أفـاد أن المـوت الدماغى لا يعتد فى مـوت الحيوانـات، فـأولى أن يكون الإنسان كذلك إذ إن "مرسوم الحيوان" الصادر عام 917 ام- القسم الأول- الفرع الرابع- يقرر أن: "الحيوان يعتبر حيا حتى يحدث توقف دائم لدورة الدم أو تدمير لدماغه، ثم قال الدكتور هيل: "ألم يحن الوقت كى نمنح المرضـى على الأقل - الحماية ذاتها التى نصر على منحها للحيوان، وأن نستخدم المعايير ذاتها القاضية بضرورة التوقف الدائم للدورة الدمويـة أو تدمير ( ) حقيقة الموت والحياة في القرآن والأحكام الشرعية ، د. توفيق الواعي، من بحوث

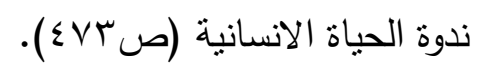


الدماغ لكى نقرر أن الموت قد حدث فعلا قبل إن نشرع فى عملية إزالة الأعضاء الحيوية.

0- تظهر الاختبارات التى تجرى للكشف عن وظائف المخ أنها ليست

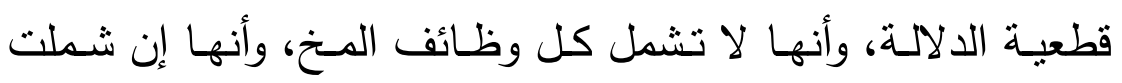
فإنها تعكس تعطل المـخ وليس موتـه، وأن الهـخ ليس أهم أعضاء

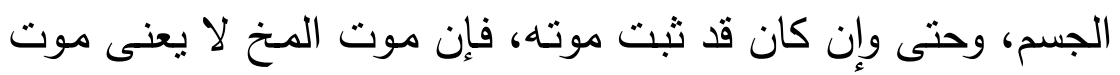

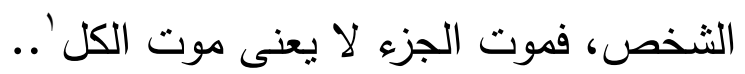

اعترض جمهور الأطباء المشاركين فى الندوة التى عقدتها المنظمة الإسلامية للعلوم الطبية عام 997 19 على هذه الحجج بما يأنى:

1- ظهور علامات الحياة على بعض المرضى المشخص حالتهم موتا دماغيا برجع إلى خطأ فى التشخيص، ولا يرجع إلى حقيقة التسليم

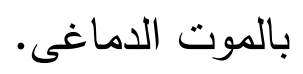
ץ- الجميع متفق على تحقق الوفاة بـالموت الدماغى، ولا توجد فروق

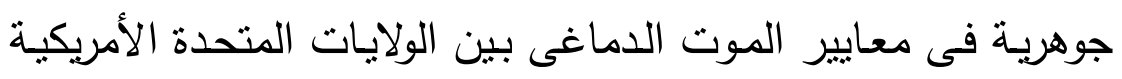
والدول الأوروبية، وادعاء وجود اختلافات يرجع إلى أمرين:

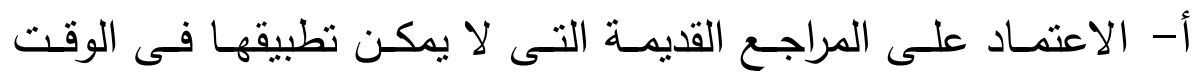

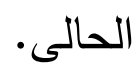

( ) حقيقة الموت والحياة في القرآن والأحكام الشرعية ، د. توفيق الواعي، من بحوث

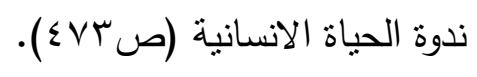


ب- - سوء فهم حقيقة هذه الاختلافات، فهى اختلافات فى الصيخ، أو تبنى الثروط، والمستوياات الإكلينيكية، وهو ما يسمى ببروتوكولات

$$
\text { موت المخ' . مونى }
$$

أما ادعاء عدم أخذ اليابان والدا نمارك بالموت الدماغى فلا يرجع إلى انكار حقيقه العلمية، وإنما يرجع - فى اليابان - إلى تقاليدها الموروثة، فاليابانيون يرون الموت شأنا عائليا بحتا، ومع ذلك فقد سسجلت اليابان فى مؤتمر سان فرانسيسكو فى نـوفمبر 979 (م، أنهـا ستصدر قرارات قادمسة قريبـا لإيجـاد الصيغ القانونية المناسبة لمفهوم موت الدماغ، وكذلك سيحدث فى الدانمارك

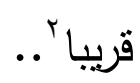

r- إن وسـائل نشخيص الموت الدماغى قد تطور جدا، ولم بعد عناك جدل بشأنها. ع - إن"مرسـوم الحيـوان" عـام 9 إم يعتمـــ المـوت الـدماغى، لتقريـره أن:"الحيوان يعتبر حيا حتى يحدث توقف دائم لدورة الدم، أو تدمير

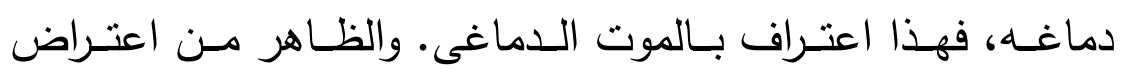
الدكتور "هيل" أنه يهاجم سرقة الأعضاء من الأحياء الفقراء، وليس

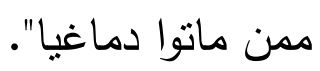

( ) حقيقة الموت والحياة في القرآن والأحكام الشرعية ، د. توفيق الواعي، من بحوث

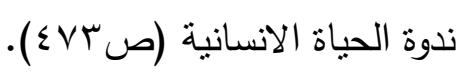
r ) حقيقة الموت والحياة في القرآن والأحكام الشرعية ، د. نوفيق الواعي، مـن بحوث

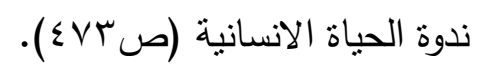


ه- القول بأن اختبارات وظائف المخ غير قطعية وتدل على تعطل المخ دون موته، وأن المخ ليس أهم أعضاء الجسم، ونحو هذا، قول ظاهر

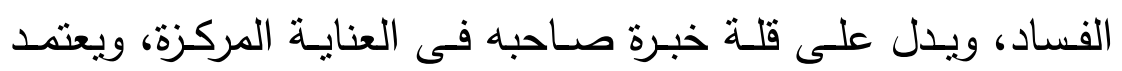
صاحبه على الصحف والمجلات دون البحوث العلمبة ومراجعها. الاتجاه الثالث: يرى أن للموت مفهومين: مفهوم طبى ومفهوم اجتماعى، ولا تصدر شهادة الوفاة إلا طبقا لمفهوم الاجتماعى. وإليـه ذهب الدكتور يوسف ريزه لـى وقريب مس هذا مـا ورد من توصسيات المنظمة الإسلامية للعلوم الطبية، حيث انتهث:" إلى أن الإنسان الذى يصل إلى مرحلـة مستيقنة هى موت جذع المـخ بعتبر قد استدبر الحياة، وأصبح صالحا لأن تجرى عليه بعض أحكام الموت". وحجة هذا الاتجاه ما يلى:

ا - إن الحقيقة التى توصل إليها التقدم الطبى فى ماهية الموت ترجهع إلىى مـوت المـخ، فكـان هـذا مفهومـا طبيـا، لا يملك الطبيب إزاءه سوى إخبار أهل المريض، وهم أصحاب الثأن فى التصرف، وفقا لواقعهم الاجتماعى. ץ- إن النشخيص النهائى لحقيقة الموت يرجع إلى حقيقة الواقع الاجتمـاعى الذى يشتمل على جوانب طبيـة وقانونيـة ودينيـة وأخلاقية. 
والذى يظهر لى أن اعتماد حكم الموت بضوابطه الطبية الدقيقة هو الأقرب والمختار؛ لأن أهل الاختصاص قررو ذلك، فالموت الدماغى هو موت للمراكز الحيوبة الواقعـة فى جذع الدماغ، فإذا ماتت هذه المنطقة فإن الإنسان يعد ميتا؛ لأن تتفسه بواسطة الآلة مهما استمر لا قيمـة لـه، ولا يعطى البـاة للإنسـان، وكذللك اسـتمرار النبض مـن القلب، بل وتدفق الدم فى الشرايين والأوردة لا يعد علامـة على الحياة طالما أن الدماغ قد توققت حياته توقفا تاما لا رجعة فيه. أما بالنسبة للفقهاء القائلين بعدمه، فجل ما بستندون عليه اليقين والموت الدماغى عندهم ظنى، والحقيقة أن العلامات الظاهرة للموت لدى الفقهاء ظنية، ليست بيقينية، بخلاف ما لاى الأطباء من وسائل تشخيصية أكثر دقة من العلامات الظنية، بدليل ما ورد ذكره فى بعض كتب الفقهاء من دفن أحياء على أنهم أموات، بناء على تلك العلامات الظاهرة. يقول

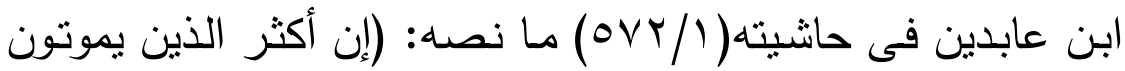
بالسكتة يدفنون وهم أحياء؛ لأنه يعسر إدراك الموت الحقيقى إلا على

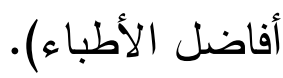




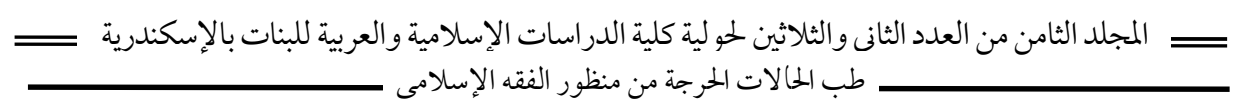

بـل أصبح الطب أكثر دقة فى تحديد المـوت، وهو مـا بقرره الفقهاء حتى القائلين منهم بعد الموت الدماغى '.

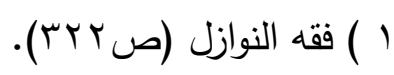




\section{النتائج والتوصبات}

ا • يعـد المـوت بالحـالات الحرجـة مـن الحـالات التـي تحتـوي المراكـز

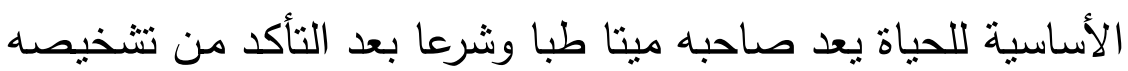

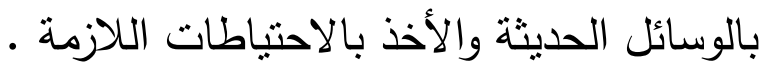

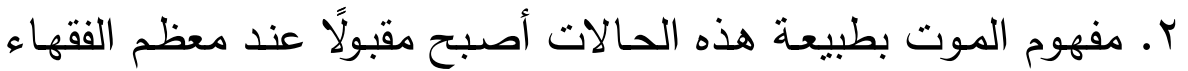

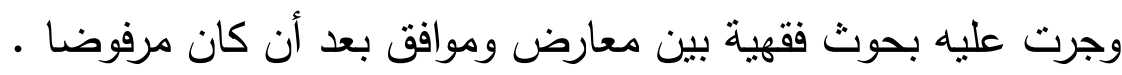

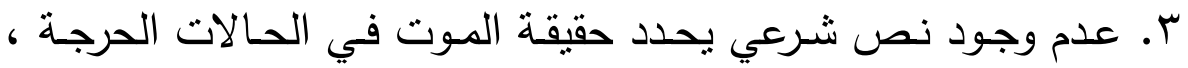

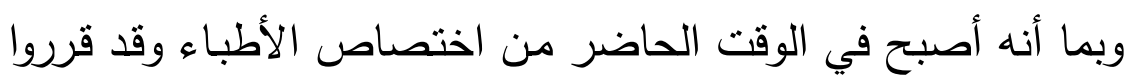

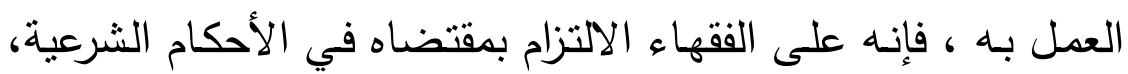

ولهذا لا يترك تتخيص الموت للفقهاء ولا لعامة الناس. 


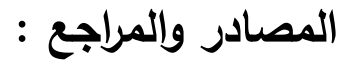

( ) الأفكار القديمـة والحديثة حول تحديد المـوت د حسن حسن

علي - الندوة الطبية - التعريف الطبي للموت .

r) تحديد المفهوم الحديث لموت الدماغ د صفوت حسن لطفي -

الندوة الطبية - التعربف الطبي للموت .

r) التعربف العلمي الطبي للموت د رؤؤف محمود سلام - الندوة

الطبية - التعريف الطبي للموت .

ع) تعريف الموت د/ فيصل عبد الرحيم شاهين - الندوة الطبية -

$$
\text { التعريف الطبي للموت . مات }
$$

ه) حقيقة الموت والحياة في القرآن والأحكام الثرعية د / توفيق

$$
\text { الواعي - ندوة الحياة الإنسانية بدايتها . }
$$

7) القلـب وعلاقتـهـ بالحيـاة د. أحمـد القاضــي - نـدوة الحيـاة

$$
\text { الانسانبة بدايتها }
$$

ما الفرق بين الموت الاكلينكي والموت الثرعي د / محمد البار - الندوة

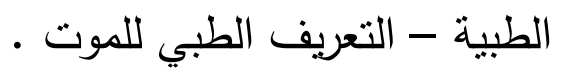

